\title{
Cupiennin 1a exhibits a remarkably broad, non-stereospecific cytolytic activity on bacteria, protozoan parasites, insects, and human cancer cells
}

\author{
Lucia Kuhn-Nentwig • Jean Willems • \\ Thomas Seebeck $\cdot$ Tarek Shalaby $\cdot$ Marcel Kaiser • \\ Wolfgang Nentwig
}

Received: 24 November 2009/ Accepted: 30 December 2009/Published online: 7 February 2010

(C) Springer-Verlag 2010

\begin{abstract}
Cupiennin 1a, a cytolytic peptide isolated from the venom of the spider Cupiennius salei, exhibits broad membranolytic activity towards bacteria, trypanosomes, and plasmodia, as well as human blood and cancer cells. In analysing the cytolytic activity of synthesised all-D- and all-L-cupiennin 1a towards pro- and eukaryotic cells, a stereospecific mode of membrane destruction could be excluded. The importance of negatively charged sialic acids on the outer leaflet of erythrocytes for the binding and haemolytic activity of L-cupiennin 1a was demonstrated. Reducing the overall negative charges of erythrocytes by partially removing their sialic acids or by protecting them with tri- or pentalysine results in reduced haemolytic activity of the peptide.
\end{abstract}

L. Kuhn-Nentwig $(\bowtie) \cdot$ W. Nentwig

Institute of Ecology and Evolution, University of Bern,

Baltzerstrasse 6, 3012 Bern, Switzerland

e-mail: lucia.kuhn@iee.unibe.ch

J. Willems

Department of Medicine Laboratory of Biochemistry,

Interdisciplinary Research Centre, K.U. Leuven,

Campus Kortrijk, 8500 Kortrijk, Belgium

T. Seebeck

Institute of Cell Biology, University of Bern,

Baltzerstrasse 4, 3012 Bern, Switzerland

T. Shalaby

Children's Hospital Zürich, University Children's Clinic,

Steinwiesstrasse 75, 8032 Zurich, Switzerland

M. Kaiser

Swiss Tropical Institute, Socinstrasse 57,

P.O. Box 4002, Basel, Switzerland
Keywords Cupiennin 1a $\cdot$ M-ctenitoxin-Cs1a .

Spider - Cupiennius salei - Cytolytic activity ·

Cancer cells $\cdot$ Protozoan parasites · Non-stereospecificity

\section{Introduction}

The hunting success of the Central American spider Cupiennius salei (Ctenidae) strongly depends on the power of its chelicerae and the paralysing/killing effect of its venom. The venom is characterised by proteins, low molecular mass compounds and peptides. Beside neurotoxins and enhancer peptides, about one-third of the venom consists of small cysteine-free peptides, the cupiennins (Kuhn-Nentwig et al. 2002b) which are also named M-ctenitoxin-Cs1a-1d according to a newly proposed toxin nomenclature (ArachnoServer spider toxin database http://www.arachnoserver.org/). These $\alpha$-helical peptides are highly cationic and exhibit strong cytolytic activities towards different prokaryotic cells and human erythrocytes (Kuhn-Nentwig et al. 2002b). A dual role is proposed for cupiennins in that: (1) due to their cytolytic activity they synergistically enhance the activity of neurotoxins and other venom peptides (Kuhn-Nentwig et al. 2004; Wullschleger et al. 2004, 2005) and (2) they protect chelicerae and venom glands against microbial infections (Kuhn-Nentwig 2003). The best investigated cytolytic peptide, cupiennin 1a, is characterised by a helix-hinge-helix structure (Pukala et al. 2007a), comparable to the structure of latarcin 2a (M-zodatoxin-Lt2a), a cytolytic peptide isolated from the venom of the central Asian spider Lachesana tarabaevi (Zodariidae) (Kozlov et al. 2006). As a linear cationic peptide, cupiennin 1a adopts $\alpha$-helical conformation in the presence of negatively charged membranes and is attracted to the membrane by electrostatic 
interactions. ${ }^{31} \mathrm{P}$ solid-state nuclear magnetic resonance (NMR) spectroscopy of different phospholipid bilayers with cupiennin 1a ( $\mathrm{Cu} 1 \mathrm{a})$ points to a possible toroidal pore formation as the mechanistic basis of its antimicrobial effect (Pukala et al. 2007a). Remarkably, Cu1a exhibits a second, non-membranolytic activity: in the submicromolar range, the peptide inhibits the formation of nitric oxide by neuronal nitric oxide synthase through complexation with the regulatory protein $\mathrm{Ca}^{2+}$ calmodulin (Pukala et al. 2007b). This indicates that the targets of Cula in a spider's prey are not only the cell membranes, but also cellular enzymes. Their inhibition, in combination with pore formation by $\mathrm{Cu} 1 \mathrm{a}$, together with the action of other venom compounds leads to the rapid destruction of vitally important systems.

Investigations concerning the antimicrobial activity of all-D and all-L enantiomers of several host defence peptides revealed that all-D enantiomers have the same or even improved antimicrobial activity due to slower enzymatic inactivation than natural all-L enantiomers (Bessalle et al. 1990; Jung et al. 2007; Kitani et al. 2009; Li et al. 2000; Mäntylä et al. 2005; McGwire et al. 2003; Thevissen et al. 2005; Vunnam et al. 1998; Wade et al. 1990; 2000), indicating a chirally independent mechanism of membrane disruption. Nevertheless, a dual mode of action is reported for a proline-rich antibacterial peptide, cathelicidin Bac7: a stereospecificity-dependent uptake and binding to an intracellular target at nearMIC concentrations and a non-stereoselective membrane disruption at higher concentrations (Podda et al. 2006).

To exclude a stereospecific cytolytic effect of all-Dcupiennin 1a (D-Cu1a) and all-L-cupiennin 1a (L-Cu1a), we performed bioassays with bacteria, trypanosomes, human erythrocytes and Drosophila melanogaster. Since we did not detect any stereospecificity, we tested the cytolytic activity of only L-Cu1a towards Plasmodium falciparum and different human blood cells as well as leukemic and tumour cells. To explore the membranespecific mode of action of L-Cula, we also analysed the involvement of sialic acids in the haemolytic activity of L-Cula by protection or partial removal of these groups.

\section{Materials and methods}

\section{Peptides}

C-terminal amidated all-L- (L-Cu1a) and all-D-cupiennin 1a (D-Cu1a) were synthesised by BACHEM AG (Bubendorf, Switzerland). Trilysine, pentalysine and neuraminidase were purchased from Sigma-Aldrich (Buchs, Switzerland).
Antimicrobial assays

Escherichia coli ATCC 25922 and Staphylococcus aureus ATCC 29213 were cultured in Mueller-Hinton broth. The bactericidal activity of the peptides was determined using a microtiter broth dilution assay ( $\mathrm{Wu}$ and Hancock 1999). The bacterial inoculum prepared from mid log phase cultures was diluted to a final concentration of $\sim 3.7 \times 10^{5} \mathrm{cfu} / \mathrm{ml}$. Twofold dilution of peptides (L-Cu1a or D-Cu1a: 0.04-2.5 $\mu \mathrm{M}$ ), non-treated growth control and a sterility control were tested sixfold as described earlier (Kuhn-Nentwig et al. 2002b). Cell growth was estimated by monitoring the optical density at $630 \mathrm{~nm}$ and the resulting colony forming units were counted after $18 \mathrm{~h}$ of incubation at $37^{\circ} \mathrm{C}$.

Trypanosoma brucei brucei MiTat1.2(221) were cultured in HMI-9 medium (Hesse et al. 1995) supplemented with $10 \%(\mathrm{v} / \mathrm{v}) \mathrm{FCS}$ at $37^{\circ} \mathrm{C}$ in a $5 \% \mathrm{CO}_{2}$ atmosphere in $25 \mathrm{~cm}^{2}$ tissue culture flasks. For toxin assays, cells were seeded into 96-well microtiter plates $(100 \mu \mathrm{l} /$ well, $1 \times 10^{4}$ cells/well). Serial peptide dilutions were added in triplicate $(5 \mu \mathrm{l} / \mathrm{well})$, and plates were incubated for 68 $72 \mathrm{~h}$ at $37^{\circ} \mathrm{C}$ in a $5 \% \mathrm{CO}_{2}$ atmosphere. At the end of this period, $10 \mu \mathrm{l} /$ well of resazurin (Sigma R7017; $0.5 \mathrm{mM}$ in PBS) were added, and incubation was continued for an additional $2 \mathrm{~h}$ before fluorescence was determined (Räz et al. 1997) (excitation at $536 \mathrm{~nm}$, emission at $588 \mathrm{~nm}$ ).

In vitro assays for detection of antiprotozoal activity against Plasmodium falciparum (K1 strain resistant to chloroquine and pyrimethamine), Trypanosoma brucei rhodesiense (bloodstream forms), and Trypanosoma cruzi (intracellular amastigotes in L-6 rat skeletal myoblasts) were carried out in duplicate as reported previously (Ganapaty et al. 2006).

\section{Cytotoxicity against L-6 cells}

Cytotoxicity assay was performed in a 96-well microtiter plate in duplicate, each well containing $100 \mu \mathrm{l}$ of RPMI 1640 medium supplemented with $1 \%$ L-glutamine $(200 \mathrm{mM})$ and $10 \%$ foetal bovine serum, and $4 \times 10^{4} \mathrm{~L}-6$ cells (a primary cell line derived from rat skeletal myoblasts). Serial L-Cu1a dilutions of seven threefold dilution steps covering a range from 90 to $0.123 \mu \mathrm{g} / \mathrm{ml}$ were prepared. After $72 \mathrm{~h}$ of incubation the plate was inspected under an inverted microscope to assure growth of the controls and sterile conditions. Subsequently, Alamar blue $(10 \mu \mathrm{l})$ was added to each well and the plate incubated for another $2 \mathrm{~h}$. The plates were then read with a Spectramax Gemini XS microplate fluorometer using an excitation wavelength of $536 \mathrm{~nm}$ and an emission wavelength of $588 \mathrm{~nm}$ (Räz et al. 1997). Data were analysed using the microplate reader software Softmax Pro. 
Insecticidal activity

Drosophila melanogaster were used to determine the insecticidal activity of the peptides. Eleven (L-Cula) and nine (D-Cu1a) different peptide concentrations between 1.5 and $29.3 \mathrm{pmol} / \mathrm{mg}$ fly (injected in a total volume of $0.05 \mu \mathrm{l}$ of insect ringer) were tested on each of 20 flies and 20 flies were used as controls $(0.05 \mu \mathrm{l}$ of insect ringer only). Calculations of the lethal doses $\mathrm{LD}_{50}(50 \%$ of the test flies died of intoxication $24 \mathrm{~h}$ post-injection) were performed as described elsewhere (Kuhn-Nentwig et al. 2000).

\section{Haemolytic activity}

Peptide (L-Cu1a or D-Cu1a; $0.2-50 \mu \mathrm{M}$ ) induced haemolysis (incubation for $1 \mathrm{~h}$ at $37^{\circ} \mathrm{C}$ ) was determined using fresh human red blood cells $\left(2.4 \times 10^{8}\right.$ cells $\left./ \mathrm{ml}\right)$. Release of haemoglobin was monitored by changes in the absorbance at $541 \mathrm{~nm}$ (Jasco V-550, Japan). The positive control (100\% haemolysis) was human erythrocytes in distilled water and the negative control ( $0 \%$ haemolysis) was human erythrocytes in phosphate-buffered saline as described in (Kuhn-Nentwig et al. 2002b).

Protection experiments with tri- or penta-lysine

The haemolytic activity of $2.5 \mu \mathrm{M}$ L-Cu1a was determined in the presence of increasing concentrations of trilysine or pentalysine. Erythrocytes $\left(1.7 \times 10^{8}\right.$ cells $\left./ \mathrm{ml}\right)$ were preincubated for $10 \mathrm{~min}$ with trilysine $(0.1-1 \mathrm{mM})$ or pentalysine $(0.1-0.5 \mathrm{mM})$ at $25^{\circ} \mathrm{C}$ in $230 \mu 1$ of PBS A $(5 \mathrm{mM}$ $\mathrm{NaH}_{2} \mathrm{PO}_{4} \times \mathrm{H}_{2} \mathrm{O}, 150 \mathrm{mM} \mathrm{NaCl}, \mathrm{pH}$ 7.2). After adding $20 \mu \mathrm{L}-\mathrm{Cu} 1 \mathrm{a}$, the erythrocytes were further incubated for $1 \mathrm{~h}$ at $37^{\circ} \mathrm{C}$. The percentage of haemolysis was calculated as mentioned above.

Sialic acid depletion of erythrocytes

Human erythrocytes (20\% haematocrit) were incubated with neuraminidase (Clostridium perfringens Type $\mathrm{V}$, Sigma, $1-80 \mu \mathrm{g} / \mathrm{ml})$ in PBS B $\left(5 \mathrm{mM} \mathrm{NaH}_{2} \mathrm{PO}_{4} \times \mathrm{H}_{2} \mathrm{O}\right.$, $150 \mathrm{mM} \mathrm{NaCl}, 0.5 \mathrm{mM} \mathrm{CaCl}_{2} \times 2 \mathrm{H}_{2} \mathrm{O}, \mathrm{pH}$ 7.2) for $1 \mathrm{~h}$ at $37^{\circ} \mathrm{C}$. Determination of released sialic acids was done with the resorcinol/ $/ \mathrm{FeCl}_{3}$ method as described (Reuter and Schauer 1994) and a calibration curve was generated with sialic acid ( $N$-acetylneuraminic acid, Type IV-S, Sigma) in a concentration range from 1 to $10 \mu \mathrm{g}$. Then, sialic acid depleted erythrocytes were washed four times with PBS A and diluted to $1.6 \times 10^{7}$ cells $/ \mathrm{ml}$. Erythrocytes were incubated with $\mathrm{L}-\mathrm{Cu} 1 \mathrm{a}(5.4 \mu \mathrm{M})$ for $1 \mathrm{~h}$ at $37^{\circ} \mathrm{C}$ and haemolysis was determined as described above.
LDH assay of human blood and cancer cells

Erythrocytes, lymphocytes, and granulocytes were obtained from anticoagulated human blood from healthy volunteers as described earlier (Willems et al. 2002). Various human cancer cells were obtained from the Rega Institute (K.U. Leuven, Belgium). Human tumour cells were cultured in RPMI-1640 medium, supplemented with $10 \%$ foetal calf serum, $2 \mathrm{mM}$ glutamine, penicillin (100 U/ $\mathrm{ml})$ and streptomycin $(100 \mu \mathrm{g} / \mathrm{ml})$ at $37^{\circ} \mathrm{C}, 5 \% \mathrm{CO}_{2}$ and 95\% relative humidity. Cells were washed with phosphatebuffered saline (PBS) buffer and directly used except for HEK, HEK/SV40 and HeLa cells, which were harvested after trypsinization and then washed with PBS buffer.

For the lactate dehydrogenase assay (LDH assay), human granulocytes, lymphocytes, erythrocytes and diverse cancer cells $\left(4-6 \times 10^{6}\right.$ cells $\left./ \mathrm{ml}\right)$ were incubated with different concentrations of L-Cu1a in $300 \mu$ of PBS buffer for $20 \mathrm{~min}$ at $37^{\circ} \mathrm{C}$. Afterwards, the samples were centrifuged and $100 \mu \mathrm{l}$ supernatant was used in the LDH assay with pyruvate as substrate and NADH as coenzyme, and measured at $340 \mathrm{~nm}$ as described (Bergmeyer and Bernt 1974).

Granulocytes and activation assays

Inhibition of superoxide production by NADPH oxidase activity was measured as follows. Granulocytes were diluted to a final concentration of $2 \times 10^{5} / \mathrm{ml}$. Lyophilized $\mathrm{L}-\mathrm{Cu} 1 \mathrm{a}(60 \mu \mathrm{g} / 50 \mu \mathrm{l})$ was dissolved in water and added to $300 \mu \mathrm{l}$ of granulocyte suspension to obtain a final concentration of $2 \times 10^{-7}$ and $5 \times 10^{-7} \mathrm{M}$ of L-Cula. After incubation for $1 \mathrm{~h}$ at $37^{\circ} \mathrm{C}, 50 \mu \mathrm{l}$ lucigenin $(0.5 \mathrm{mg} / \mathrm{ml})$ was added and the background chemiluminescence was measured. Then $50 \mu \mathrm{l}$ phorbol myristate acetate (PMA, $1 \mu \mathrm{g} / \mathrm{ml}$ ) was added and superoxide production was measured for 10-15 min using a Biolumat 9505 (Berthold, Germany) apparatus. Peak luminescence values were compared and inhibition was calculated as a percentage of superoxide production produced by PMA in control samples (no cytolytic peptide present).

The chemotaxis assay was performed using 24-well plates (Transwell-Costar, pore size $3 \mathrm{~mm}$ ). Upper wells $(200 \mathrm{ml})$ contained granulocytes $\left( \pm 10^{6} / \mathrm{ml}\right)$, and lower wells $(400 \mu \mathrm{l}) \mathrm{L}-\mathrm{Cu} 1 \mathrm{a}$ or control. At the end of the $1 \mathrm{~h}$ experiment (at $37^{\circ} \mathrm{C}$ ) a cell sample was taken from both compartments and counted. The migration ratio was calculated. Both negative (no L-Cu1a) and positive controls (formylated tripeptide fMLP, $3 \times 10^{-8} \mathrm{M}$ ) were included and results expressed in relation to the value for fMLP (set $=100 \%)$. 
The human cells (leucocytes and erythrocytes) were obtained after informed consent according to the ethical guidelines of the K.U. Leuven, Belgium, and the guidelines for researcher of the University Bern, Switzerland.

For statistics, the peptide concentrations at which 50\% haemolysis, cell growth inhibition or inhibition of cell viability was observed $\left(\mathrm{EC}_{50} ; \mathrm{IC}_{50}\right)$ were derived using sigmoidal curve fitting software (GraphPad Prism 4.0, Graph Pad Software).

\section{Results and discussion}

Cytolytic activity of D-Cu1a and L-Cu1a enantiomers on trypanosomes, bacteria, human erythrocytes and insects

The cytolytic activity of different concentrations of D-Cu1a and L-Cu1a on diverse membrane types is mostly within a comparable submicromolar range (Fig. 1). The
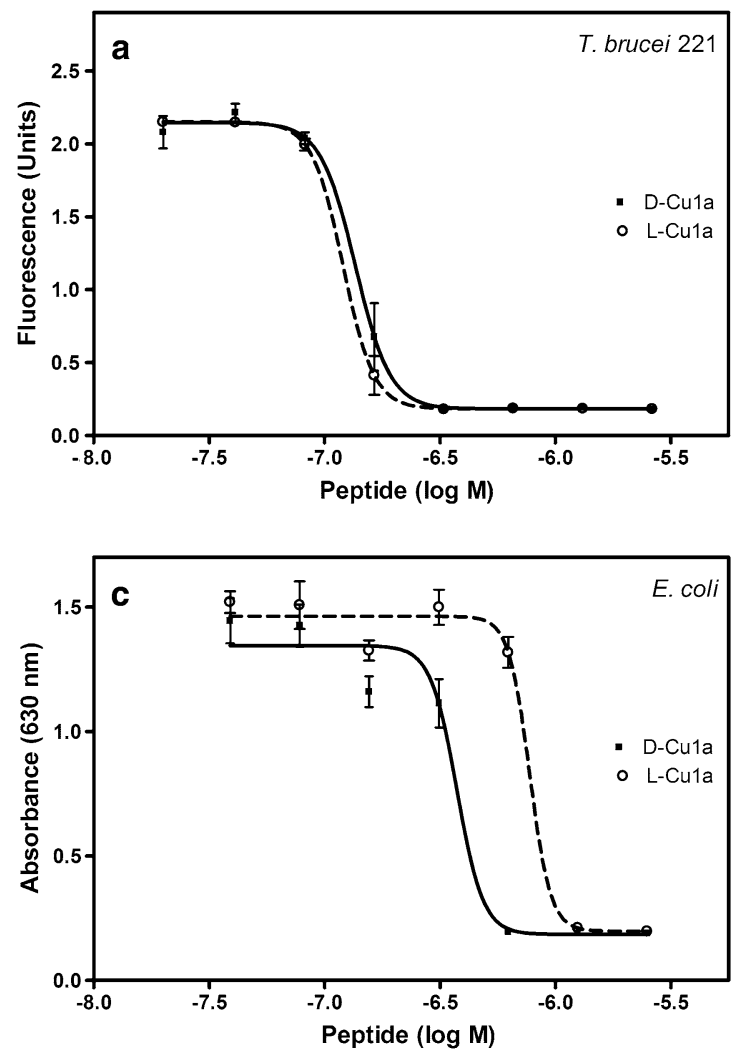

Fig. 1 Cytolytic activity of D- and L-enantiomers of Cu1a towards trypanosomes, human erythrocytes and bacteria. a Trypanosomes $\left(10^{5}\right.$ cells $/ \mathrm{ml}$; bloodstream form) were incubated for $72 \mathrm{~h}$ at $37^{\circ} \mathrm{C}$ with twofold dilution steps of D-Cu1a and L-Cula (highest peptide concentration $2.63 \mu \mathrm{M})$. Cell viability was monitored with the Alamar blue assay and fluorescence was measured with excitation at $536 \mathrm{~nm}$ and emission at $588 \mathrm{~nm}$. b Human erythrocytes $\left(2.4 \times 10^{8}\right.$ cells $\left./ \mathrm{ml}\right)$ were incubated for $1 \mathrm{~h}$ at $37^{\circ} \mathrm{C}$ with different trypanocidal activity of the enantiomers exhibits no major differences, with an $\mathrm{IC}_{50}$ of $0.136 \mu \mathrm{M}$ for $\mathrm{D}-\mathrm{Cula}$ and $0.120 \mu \mathrm{M}$ for L-Cu1a (Fig. 1a). The microscopically observed minimal inhibition concentrations (MIC) for both peptides were estimated at $0.328 \mu \mathrm{M}$ for T. brucei 221 . In addition, no differences are visible in their haemolytic activity (Fig. 1b), with an $\mathrm{EC}_{50}$ of $3.32 \mu \mathrm{M}$ (D-Cu1a) and $3.10 \mu \mathrm{M}$ (L-Cu1a). However, the bactericidal activity of D$\mathrm{Cu} 1 \mathrm{a}\left(\mathrm{IC}_{50} 0.375 \mu \mathrm{M}\right)$ towards $E$. coli was twofold higher than determined for the L-variant $\left(\mathrm{IC}_{50} 0.774 \mu \mathrm{M}\right)$, and towards $S$. aureus threefold higher for the D-variant $\left(\mathrm{IC}_{50} 0.119 \mu \mathrm{M}\right)$ than for the L-variant $\left(\mathrm{IC}_{50} 0.383 \mu \mathrm{M}\right)$ (Fig. $1 \mathrm{c}$, d). Both enantiomers were similarly active against $E$. coli $\left(\mathrm{IC}_{50}=0.63-1.25 \mu \mathrm{M}\right)$, but showed slightly different activities against $S$. aureus (L-Cu1a: 0.63$1.25 \mu \mathrm{M}$; D-Cu1a: $0.32-0.63 \mu \mathrm{M}$ ). As to the insecticidal activity, the L-variant is about twofold less potent than D-Cu1a $\left(\mathrm{LD}_{50} 2.9 \mathrm{pmol} / \mathrm{mg}\right.$ fly), with an $\mathrm{LD}_{50}$ of $6.8 \mathrm{pmol} /$ $\mathrm{mg}$ fly. To explain these small differences in the activity of D-Cu1a towards bacteria and D. melanogaster we note
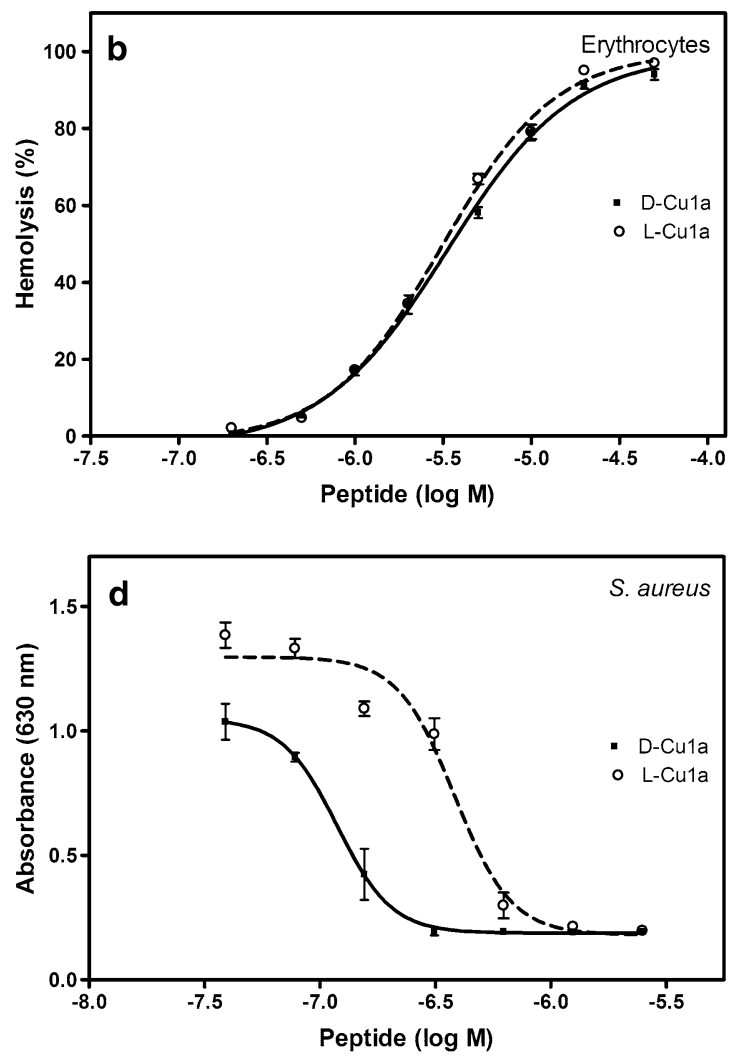

concentrations of D-Cu1a and L-Cu1a $(0.2-50 \mu \mathrm{M})$ and haemolysis was measured at $541 \mathrm{~nm}$. (c and d) The bactericidal activity of DCu1a and L-Cu1a $(0.04-100 \mu \mathrm{M})$ towards E. coli and S. aureus $\left(\sim 3.7 \times 10^{5} \mathrm{cfu} / \mathrm{ml}\right)$ was determined with the microtiter broth dilution assay. Cell growth was estimated by monitoring optical density at $630 \mathrm{~nm}$ and counting the resulting colony forming units after $18 \mathrm{~h}$ of incubation at $37^{\circ} \mathrm{C}$ 
that D-enantiomers are more resistant to degradation by proteases, which could be released into the media by bacteria and are present in flies after peptides injection due to tissue damage (Alvarez-Bravo et al. 1994; Bessalle et al. 1990; Vunnam et al. 1998). In the case of bacteria, both enantiomers are attracted by negatively charged phospholipids and lipopolysaccharides on the highly negatively charged outer membrane surfaces, resulting in $\alpha$-helical conformation of the peptide and subsequent membrane disruption in a non-stereospecific manner. The cell surface of the bloodstream form of $T$. brucei is characterised by a dense monolayer of homodimers of surface glycoproteins (VSG) of approximately $15 \mathrm{~nm}$ thickness, which is net neutral at $\mathrm{pH} 8$ (M.A. Ferguson, personal communication) (Mehlert et al. 1998). The VSG layer acts as a macromolecular diffusion barrier only for molecules above $20 \mathrm{kDa}$ (Mehlert et al. 2002). Remarkably, the plasma membrane of $T$. brucei exhibits a very high cholesterol/phospholipid ratio of 1.54 (Voorheis et al. 1979) but it has also a high content of negatively charged phosphatidylserine and phosphatidylinositol. This could allow the enantiomers to electrostatically interact with the cell membrane, thus inducing severe damage as has been reported for insect defensin-derived synthetic peptides (Kitani et al. 2009; Patnaik et al. 1993). In addition, a high content of lipid-bound sialic acid residues have been determined for bloodstream forms of T. brucei brucei (Carroll and McCrorie 1986). These might also contribute to the electrostatic attraction of the peptides. Incubation of T. brucei with melittin, a cytolytic peptide isolated from honey bee venom in submicromolar concentrations, resulted in a calcium influx into the parasites without disrupting cell permeability, which only occurs at higher concentrations (Ruben et al. 1996). Our results also support other reports concerning the trypanocidal activity of several antimicrobially acting peptides of diverse origin which act by disrupting membrane integrity (Boulanger et al. 2002; Kitani et al. 2009; Löfgren et al. 2008; McGwire et al. 2003; Yamage et al. 2009).

Due to the fact that no stereospecific effects of Culaenantiomers on diverse membrane types could be demonstrated, the susceptibility of three further pathogenic eukaryotic parasites was investigated only with L-Cula. All three parasites, $T$. brucei rhodesiense (sleeping sickness), T. cruzi (Chagas' disease) and P. falciparum (malaria tropica) are sensitive to the peptide in the submicromolar range (Table 1). Unexpectedly, rat skeletal myoblasts (L-6 cells), used as a control for cytotoxicity, exhibit an $\mathrm{IC}_{50}$ of $0.342 \mu \mathrm{M}$; thus, these myoblasts are up to three times more sensitive than T. cruzi. The high susceptibility of L-6 cells towards L-Cu1a could possibly be explained by the presence of sialic acids on the cell surface (De Bank et al. 2003), which could be responsible for membrane binding and lysis by L-Cula.

The attraction of antimicrobial peptides due to negative charges of diverse bacterial membrane structures
Table 1 Cytolytic effects of L-Cu1a on protozoan parasites with $\mathrm{IC}_{50}$ inhibitory concentrations of two independent assays (A and B)

\begin{tabular}{llll}
\hline Cell type & Cells/ml & \multicolumn{2}{l}{$\mathrm{IC}_{50}(\mu \mathrm{M})$} \\
\cline { 3 - 4 } & & $\mathrm{A}$ & $\mathrm{B}$ \\
\hline $\begin{array}{l}\text { Eukaryotic parasites } \\
\begin{array}{l}\text { Trypanosoma brucei } \\
\text { rhodesiense }\end{array}\end{array}$ & $1.0 \times 10^{5}$ & 0.055 & 0.061 \\
$\begin{array}{l}\text { Trypanosoma cruzi } \\
\text { Plasmodium falciparum }\end{array}$ & $\begin{array}{l}2.5 \% \text { haematocrit } \\
(0.3 \% \text { parasitaemia) }\end{array}$ & 0.029 & 0.034 \\
& & & \\
$\begin{array}{l}\text { Eukaryotic control cell } \\
\text { Rat skeletal myoblasts } \\
\text { (L-6 cells) }\end{array}$ & $4.0 \times 10^{5}$ & & \\
\hline
\end{tabular}

(lipopolysaccharides, phosphatidylglycerol, diphosphatidylglycerol) is beyond doubt, whereas the binding of cytolytic and antimicrobial peptides and subsequent cell membrane damage of erythrocytes are still poorly understood (Lohner 2001). In the cytotoxicity standard test of antimicrobial peptides towards eukaryotic cells, erythrocytes are mainly used because they are abundant and easy to isolate. Human erythrocytes are characterised by an asymmetric distribution of phospholipids in its membrane. Negatively charged phosphatidylserine is located only in the inner leaflet, whereas the outer leaflet is composed of sphingomyelin, phosphatidylcholine, phosphatidylethanolamine and cholesterol (Verkleij et al. 1973). The overall negative charge of the erythrocytes is reduced to different carbohydrate structures containing sialic acids (Viitala and Järnefelt 1985). Thus, a possible role for sialic acids as a factor which regulates the haemolytic activity of L-Cu1a could be tested by modifying human erythrocytes. Subsequent removal of sialic acid from the surface of human erythrocytes results in a $\sim 20 \%$ reduction of haemolysis caused by L-Cu1a, as demonstrated in Fig. 2. In addition, reducing the overall negative charge of the human erythrocyte surface by application of increasing concentrations of trilysine and pentalysine before incubation with L-Cula, strongly reduces the haemolytic activity of cytolytic peptide (Fig. 3). These combined observations point to the impact of the total surface charge of erythrocytes. In this experiment 29-h-old erythrocytes were used, which exhibit a higher susceptibility to $\mathrm{L}-\mathrm{Cu} 1 \mathrm{a}(2.5 \mu \mathrm{M} \mathrm{L}-\mathrm{Cu} 1 \mathrm{a}$ causes $\sim 90 \%$ haemolysis $)$ than fresh erythrocytes $(2.5 \mu \mathrm{M} \mathrm{L}$ Cula causes $\sim 40 \%$ haemolysis). It seems that the negatively charged sialic acids on the cell surface of erythrocytes enable L-Cu1a to adopt an $\alpha$-helical conformation, resulting in membrane binding by electrostatic attraction. In spite of lacking negatively charged phospholipids in the outer membrane, damage to the cell membrane occurs by insertion of the hydrophobic N-terminal part of $\mathrm{L}-\mathrm{Cu} 1 \mathrm{a}$ via 


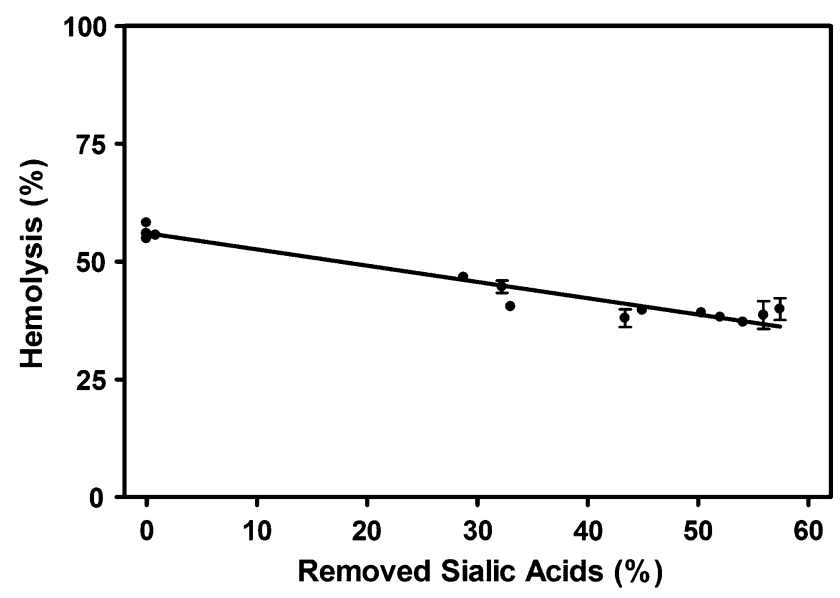

Fig. 2 Partial sialic acid depletion of human erythrocytes reduces the cytolytic activity of L-Cula. Sialic acids were removed from fresh erythrocytes (20\% hematocrit) by incubation with different concentrations of neuraminidase. Afterwards, erythrocytes $(\sim 1.6 \times$ $10^{7}$ cells $/ \mathrm{ml}$ ) were incubated with $5.4 \mu \mathrm{M} \mathrm{L}-\mathrm{Cu} 1 \mathrm{a}$ for $1 \mathrm{~h}$ at $37^{\circ} \mathrm{C}$ and haemolytic activity was measured at $541 \mathrm{~nm}$

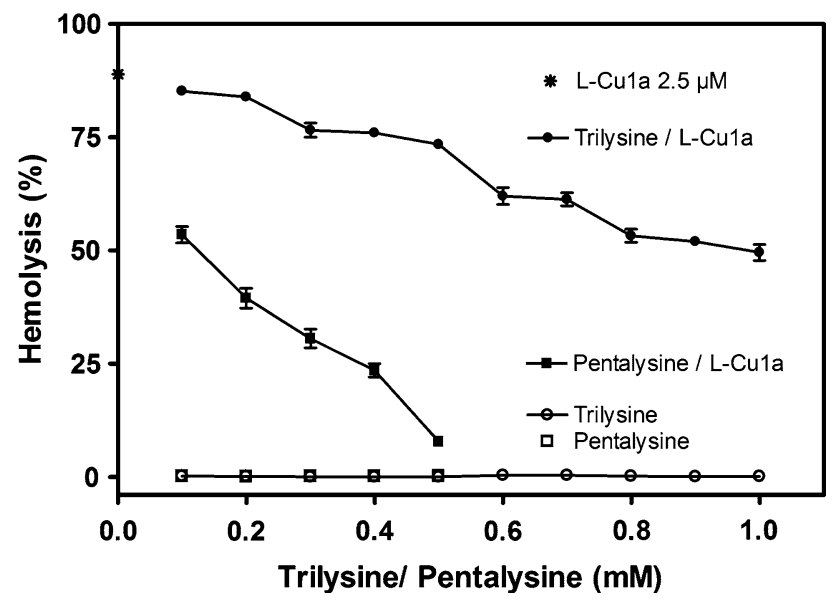

Fig. 3 Preincubation of human erythrocytes with different concentrations of trilysine or pentalysine reduces the cytolytic activity of LCu1a. Here, 29-h-old erythrocytes $\left(\sim 1.7 \times 10^{8}\right.$ cells $\left./ \mathrm{ml}\right)$ were preincubated for $10 \mathrm{~min}$ at $25^{\circ} \mathrm{C}$ with different concentrations of tri- or penta-lysine. After incubation with $2.5 \mu \mathrm{M} \mathrm{L}-\mathrm{Cu} 1 \mathrm{a}$ for $1 \mathrm{~h}$ at $37^{\circ} \mathrm{C}$ haemolytic activity was measured as change in the absorbance at $541 \mathrm{~nm}$

a chirally independent mechanism (Kuhn-Nentwig et al. 2002a; Pukala et al. 2007a).

Effects of L-Cu1a on different human cells

The cytolytic effect of L-Cu1a on different normal human blood cells, leukemic and tumour cells exhibits considerable differences (Table 2). Considering lytic activity, granulocytes and lymphocytes are about 40-50 times more sensitive to L-Cu1a compared with human erythrocytes $\left(\mathrm{EC}_{50} 23 \mu \mathrm{M}\right)$. The production of superoxide by the NADPH oxidase in PMA stimulated granulocytes is
Table 2 Effect of L-Cu1a on different human cells and cell lines

\begin{tabular}{lcl}
\hline $\begin{array}{l}\text { Cell type } \\
\left(4-6 \times 10^{6} \text { cells/ml }\right)\end{array}$ & $\mathrm{EC}_{50}(\mu \mathrm{M})$ & $\begin{array}{l}95 \% \text { confidence } \\
\text { intervals }\end{array}$ \\
\hline $\begin{array}{l}\text { Human blood cells } \\
\text { Erythrocytes }\end{array}$ & 23.0 & $17.2-30.9$ \\
Granulocytes & 0.47 & $0.44-0.50$ \\
Lymphocytes & 0.56 & $0.54-0.60$ \\
Human leukemic cells & & \\
Raji & 0.19 & $0.16-0.23$ \\
HL-60 & 0.23 & $0.20-0.25$ \\
Sup T1 & 0.23 & $0.16-0.32$ \\
Molt 4 & 0.33 & $0.30-0.36$ \\
THP-1 & 0.35 & $0.30-0.41$ \\
Human tumour cells & & \\
HeLa & 0.15 & $0.13-0.17$ \\
HEK & 0.16 & $0.14-0.19$ \\
HEK/SV40 & 0.46 & $0.41-0.53$ \\
\hline
\end{tabular}

$E C_{50}$ The effective dose for $50 \%$ cell death

inhibited to $90 \%$ (99\%) in the presence of $0.2 \mu \mathrm{M}(0.5 \mu \mathrm{M})$ L-Cu1a. This inhibition occurs in about the same concentration range as reported for parabutoporin and opistoporin, cationic pore forming peptides isolated from the venom of South African scorpions (Willems et al. 2002, 2004). The latter are also chemotactic for granulocytes but, in contrast to these results, no induction of a granulocyte chemotactic response could be observed with $\mathrm{L}-\mathrm{Cu}$ la in concentrations between 0.2 and $0.8 \mu \mathrm{M}$.

Furthermore, different human leukemic cell lines are 66-121 times more sensitive to L-Cula than human erythrocytes. Among the human tumour cells tested, HeLa are the most sensitive $\left(\mathrm{EC}_{50}\right.$ of $\left.0.15 \mu \mathrm{M}\right)$. Interestingly, HEK 293 tumour cells are about 2.9-fold more sensitive to the peptide than HEK 293-T cells. The latter cell line differs from HEK 293 in that it expresses, in rafts on the cell membrane, SV40 large T antigen. This protein contains many lysine and arginine residues at critical places (Henning and Lange-Mutschler 1983; Walser et al. 1989). The reduction of the overall negative charge of the cells by the positively charged amino acids could lower the binding possibilities for $\mathrm{L}-\mathrm{Cu} 1 \mathrm{a}$, resulting in less sensitive HEK 293-T cells. A comparable charge-dependent targeting of cationic dextran to different tumour cell lines is proposed in which the compound binds to sialic acid residues of different cancer cells, resulting in membrane disturbance and subsequently cell death (Márquez et al. 2004). In general, cancer cells are characterised by a higher content of phosphatidylserine, increased levels of sialic acids on the outer leaflet and high negative transmembrane potentials, which could allow interaction between the cells and antimicrobial/cytolytic peptides (Dennison et al. 2006). 


\section{Conclusions}

Invertebrate host defence peptides are potentially active against a large variety of microorganisms, but are non- to low-toxic for vertebrate cells. In contrast, some cytolytic and antimicrobial peptides isolated from different venom sources, e.g. cupiennins or melittin, are able to destroy a great variety of cell types, including eukaryotic cells like myoblasts, and various blood and cancer cells. The molecular basis for this discrimination (host defence peptides) or non-discrimination (cytolytic peptides) is still poorly understood (Hoskin and Ramamoorthy 2008). The results presented here suggest that besides negatively charged phospholipids of the target cells, the overall negative charge as mediated by different acidic compounds of the cell membranes (sialic acids in the case of erythrocytes, myoblasts, or leukemic cancer cells) contributes to their susceptibility to L-Cu1a. As previously reported, L-Cu1a exhibits strong synergistic effects on the neurotoxic activity of different neurotoxins (Kuhn-Nentwig et al. 2004; Wullschleger et al. 2005). In the case of insects, muscle cells as well as nerves are encircled by basement membranes rich in acidic proteins such as glutactin and papilin; glia cells are enriched with negatively charged arthrosides (Kramerova et al. 2000; Olson et al. 1990; Sickmann et al. 1992). Destroying these negatively charged membranes by diverse cupiennins could result in better access to their targets for the neurotoxins, e.g. different ion channels. With respect to the occurrence of different negatively charged cell structures in mammals (basement membranes, nervous tissues, internal surface of normal blood vessels, etc.), Cu1a as a "cytolytic all-rounder" is not suitable for the development of new antibiotics. Nevertheless, an understanding of the molecular basis for this broad cytolytic activity and unwanted cytotoxic activity of antimicrobial peptides on negatively charged cells and tissue types in mammals is very important in the development of new antibiotics.

Acknowledgments We thank Dr. Heather Murray for critical comments on the manuscript, and the Swiss National Science Foundation for funding.

\section{References}

Alvarez-Bravo J, Kurata S, Natori S (1994) Novel synthetic antimicrobial peptides effective against methicillin-resistant Staphylococcus aureus. Biochem J 302:535-538

Bergmeyer H, Bernt E (1974) Lactate dehydrogenase: UV assay with pyruvate and NADH. In: Bergmeyer $\mathrm{H}$ (ed) Methods of enzymatic analysis. Verlag Chemie, Weinheim, pp 574-579

Bessalle R, Kapitkovsky A, Gorea A, Shalit I, Fridkin M (1990) AllD-magainin: chirality, antimicrobial activity and proteolytic resistance. FEBS Lett 274:151-155
Boulanger N, Brun R, Ehret-Sabatier L, Kunz C, Bulet P (2002) Immunopeptides in the defense reactions of Glossina morsitans to bacterial and Trypanosoma brucei brucei infections. Insect Biochem Mol Biol 32:369-375

Carroll M, McCrorie P (1986) Lipid composition of bloodstream forms of Trypanosoma brucei brucei. Comp Biochem Physiol B 83:647-651

De Bank PA, Kellam B, Kendall DA, Shakesheff KM (2003) Surface engineering of living myoblasts via selective periodate oxidation. Biotechnol Bioeng 81:800-808

Dennison SR, Whittaker M, Harris F, Phoenix DA (2006) Anticancer alpha-helical peptides and structure/function relationships underpinning their interactions with tumour cell membranes. Curr Protein Pept Sci 7:487-499

Ganapaty S, Steve Thomas P, Karagianis G, Waterman PG, Brun R (2006) Antiprotozoal and cytotoxic naphthalene derivatives from Diospyros assimilis. Phytochemistry 67:1950-1956

Henning R, Lange-Mutschler J (1983) Tightly associated lipids may anchor SV40 large $\mathrm{T}$ antigen in plasma membrane. Nature 305:736-738

Hesse F, Selzer P, Mühlstadt K, Duszenko M (1995) A novel cultivation technique for long-term maintenance of bloodstream form trypanosomes in vitro. Mol Biochem Parasitol 70:157-166

Hoskin DW, Ramamoorthy A (2008) Studies on anticancer activities of antimicrobial peptides. Biochim Biophys Acta 1778:357-375

Jung HJ, Park Y, Sung WS, Suh BK, Lee J, Hahm KS, Lee DG (2007) Fungicidal effect of pleurocidin by membrane-active mechanism and design of enantiomeric analogue for proteolytic resistance. Biochim Biophys Acta 1768:1400-1405

Kitani H, Naessens J, Kubo M, Nakamura Y, Iraqi F, Gibson J, Yamakawa M (2009) Synthetic nonamer peptides derived from insect defensin mediate the killing of African trypanosomes in axenic culture. Parasitol Res 105:217-225

Kozlov SA, Vassilevski AA, Feofanov AV, Surovoy AY, Karpunin DV, Grishin EV (2006) Latarcins, antimicrobial and cytolytic peptides from the venom of the spider Lachesana tarabaevi (Zodariidae) that exemplify biomolecular diversity. J Biol Chem 281:20983-20992

Kramerova IA, Kawaguchi N, Fessler LI, Nelson RE, Chen YL, Kramerov AA, Kusche-Gullberg M, Kramer JM, Ackley BD, Sieron AL, Prockop DJ, Fessler JH (2000) Papilin in development; a pericellular protein with a homology to the Adamts metalloproteinases. Development 127:5475-5485

Kuhn-Nentwig L (2003) Antimicrobial and cytolytic peptides of venomous arthropods. Cell Mol Life Sci 60:2651-2668

Kuhn-Nentwig L, Schaller J, Kämpfer U, Imboden H, Malli H, Nentwig W (2000) A lysine rich C-terminal tail is directly involved in the toxicity of CSTX-1, a neurotoxic peptide from the venom of the spider Cupiennius salei. Arch Insect Biochem Physiol 44:101-111

Kuhn-Nentwig L, Dathe M, Walz A, Schaller J, Nentwig W (2002a) Cupiennin $1 \mathrm{~d}^{*}$ : the cytolytic activity depends on the hydrophobic $\mathrm{N}$-terminus and is modulated by the polar C-terminus. FEBS Lett 527:193-198

Kuhn-Nentwig L, Müller J, Schaller J, Walz A, Dathe M, Nentwig W (2002b) Cupiennin 1, a new family of highly basic antimicrobial peptides in the venom of the spider Cupiennius salei (Ctenidae). J Biol Chem 277:11208-11216

Kuhn-Nentwig L, Schaller J, Nentwig W (2004) Biochemistry, toxicology and ecology of the venom of the spider Cupiennius salei (Ctenidae). Toxicon 43:543-553

Li ML, Liao RW, Qiu JW, Wang ZJ, Wu TM (2000) Antimicrobial activity of synthetic all-D mastoparan M. Int J Antimicrob Agents 13:203-208

Löfgren SE, Miletti LC, Steindel M, Bachère E, Barracco MA (2008) Trypanocidal and leishmanicidal activities of different 
antimicrobial peptides (AMPs) isolated from aquatic animals. Exp Parasitol 118:197-202

Lohner K (2001) The role of membrane lipid composition in cell targeting of antimicrobial peptides. In: Lohner K (ed) Development of novel antimicrobial agents: emerging strategies. Horizon Scientific Press, Wymondham, pp 149-165

Mäntylä T, Sirola H, Kansanen E, Korjamo T, Lankinen H, Lappalainen K, Valimaa AL, Harvima I, Narvanen A (2005) Effect of temporin A modifications on its cytotoxicity and antimicrobial activity. APMIS 113:497-505

Márquez M, Nilsson S, Lennartsson L, Liu Z, Tammela T, Raitanen M, Holmberg AR (2004) Charge-dependent targeting: results in six tumor cell lines. Anticancer Res 24:1347-1351

McGwire BS, Olson CL, Tack BF, Engman DM (2003) Killing of African trypanosomes by antimicrobial peptides. J Infect Dis 188:146-152

Mehlert A, Richardson JM, Ferguson MA (1998) Structure of the glycosylphosphatidylinositol membrane anchor glycan of a class-2 variant surface glycoprotein from Trypanosoma brucei. J Mol Biol 277:379-392

Mehlert A, Bond CS, Ferguson MA (2002) The glycoforms of a Trypanosoma brucei variant surface glycoprotein and molecular modeling of a glycosylated surface coat. Glycobiology 12:607-612

Olson PF, Fessler LI, Nelson RE, Sterne RE, Campbell AG, Fessler JH (1990) Glutactin, a novel Drosophila basement membranerelated glycoprotein with sequence similarity to serine esterases. EMBO J 9:1219-1227

Patnaik PK, Field MC, Menon AK, Cross GA, Yee MC, Bütikofer P (1993) Molecular species analysis of phospholipids from Trypanosoma brucei bloodstream and procyclic forms. Mol Biochem Parasitol 58:97-105

Podda E, Benincasa M, Pacor S, Micali F, Mattiuzzo M, Gennaro R, Scocchi M (2006) Dual mode of action of Bac7, a proline-rich antibacterial peptide. Biochim Biophys Acta 1760:1732-1740

Pukala TL, Boland MP, Gehman JD, Kuhn-Nentwig L, Separovic F, Bowie JH (2007a) Solution structure and interaction of cupiennin 1a, a spider venom peptide, with phospholipid bilayers. Biochemistry 46:3576-3585

Pukala TL, Doyle JR, Llewellyn LE, Kuhn-Nentwig L, Apponyi MA, Separovic F, Bowie JH (2007b) Cupiennin1a, an antimicrobial peptide from the venom of the neotropical wandering spider Cupiennius salei, also inhibits the formation of nitric oxide by neuronal nitric oxide synthase. FEBS J 274:1778-1784

Räz B, Iten M, Grether-Buhler Y, Kaminsky R, Brun R (1997) The Alamar Blue(R) assay to determine drug sensitivity of African trypanosomes (T. b. rhodesiense and T. b. gambiense) in vitro. Acta Trop 68:139-147

Reuter G, Schauer R (1994) Determination of sialic acids. In: Lennarz J, Hart G (eds) Methods in enzymology. Guide to techniques in glycobiology. Academic Press, London New York, pp 168-199

Ruben L, Akins CD, Haghighat NG, Xue L (1996) Calcium influx in Trypanosoma brucei can be induced by amphiphilic peptides and amines. Mol Biochem Parasitol 81:191-200

Sickmann T, Weske B, Dennis RD, Mohr C, Wiegandt H (1992) Chemical distribution of glycosphingolipids in third-instar larval organs of the blowfly, Calliphora vicina (Insecta: Diptera). J Biochem 111:662-669

Thevissen K, Francois IE, Sijtsma L, van Amerongen A, Schaaper WM, Meloen R, Posthuma-Trumpie T, Broekaert WF, Cammue BP (2005) Antifungal activity of synthetic peptides derived from Impatiens balsamina antimicrobial peptides Ib-AMP1 and IbAMP4. Peptides 26:1113-1119

Verkleij AJ, Zwaal RF, Roelofsen B, Comfurius P, Kastelijn D, van Deenen LL (1973) The asymmetric distribution of phospholipids in the human red cell membrane. A combined study using phospholipases and freeze-etch electron microscopy. Biochim Biophys Acta 323:178-193

Viitala J, Järnefelt $\mathbf{J}$ (1985) The red cell surface revisited. TIBS 10:392-395

Voorheis HP, Gale JS, Owen MJ, Edwards W (1979) The isolation and partial characterization of the plasma membrane from Trypanosoma brucei. Biochem J 180:11-24

Vunnam S, Juvvadi P, Rotondi KS, Merrifield RB (1998) Synthesis and study of normal, enantio, retro, and retroenantio isomers of cecropin A-melittin hybrids, their end group effects and selective enzyme inactivation. J Pept Res 51:38-44

Wade D, Boman A, Wahlin B, Drain CM, Andreu D, Boman HG, Merrifield RB (1990) All-D amino acid-containing channelforming antibiotic peptides. Proc Natl Acad Sci USA 87:47614765

Wade D, Silberring J, Soliymani R, Heikkinen S, Kilpelainen I, Lankinen H, Kuusela P (2000) Antibacterial activities of temporin A analogs. FEBS Lett 479:6-9

Walser A, Rinke Y, Deppert W (1989) Only a minor fraction of plasma membrane-associated large $\mathrm{T}$ antigen in simian virus 40 transformed mouse tumor cells (mKSA) is exposed on the cell surface. J Virol 63:3926-3933

Willems J, Noppe W, Moerman L, van der Walt J, Verdonck F (2002) Cationic peptides from scorpion venom can stimulate and inhibit polymorphonuclear granulocytes. Toxicon 40:1679-1683

Willems J, Moerman L, Bosteels S, Bruyneel E, Ryniers F, Verdonck F (2004) Parabutoporin-an antibiotic peptide from scorpion venom - can both induce activation and inhibition of granulocyte cell functions. Peptides 25:1079-1084

Wu MH, Hancock REW (1999) Interaction of the cyclic antimicrobial cationic peptide bactenecin with the outer and cytoplasmic membrane. J Biol Chem 274:29-35

Wullschleger B, Kuhn-Nentwig L, Tromp J, Kämpfer U, Schaller J, Schürch S, Nentwig W (2004) CSTX-13, a highly synergistically acting two-chain neurotoxic enhancer in the venom of the spider Cupiennius salei (Ctenidae). Proc Natl Acad Sci USA 101:11251-11256

Wullschleger B, Nentwig W, Kuhn-Nentwig L (2005) Spider venom: enhancement of venom efficacy mediated by different synergistic strategies in Cupiennius salei. J Exp Biol 208:2115-2121

Yamage M, Yoshiyama M, Grab DJ, Kubo M, Iwasaki T, Kitani H, Ishibashi J, Yamakawa M (2009) Characteristics of novel insect defensin-based membrane-disrupting trypanocidal peptides. Biosci Biotechnol Biochem 73:1520-1526 